http://dx.doi.org/10.12775/szhf.2015.054

\author{
LIUDMYLA OROKHOVSKA
}

National Aviation University, Kiev, Ukraine

OLA-2011@UKR.NET

\title{
Cultural and Civilizational Dimension of Ukraine in S. Rudnytsky's Philosophy
}

The combination of different cultures and civilizations on the territory of Ukraine resulted in the formation and development of the modern Ukrainian community, its relations with the East and the West, and its own cultural and civilizational identity. The cultural and civilizational axis of the "EastWest" development has remained a factor of the choice and strain inside the Ukrainian community for one thousand years in the history of Ukraine. The geographical location of our country on the path between Europe and Asia - being on the verge of cultures and local civilizations - made Ukraine a buffer in its relations with the West and the East. Thus, the features of Ukraine's cultural development have a combination of Eastern and Western mentality, attitude, and lifestyle, which is reflected in social theories.

The crisis in the Ukrainian church, social, political and cultural life in the nineteenth century required finding ways of renovation via the national revival. The awakening of political life in Galicia is observed in the midnineteenth century and in the Russian part of Ukraine - in the end of the nineteenth and early twentieth centuries. At that time in Ukraine amongst the intellectuals there appeared a cohort of personalities who turned people from passive into active community, and who was able to defend national and political interests. Among them there was S. Rudnytsky (1877-1937) - 
the founder of the Ukrainian geographic science, a philosopher, a historian, and an ethnographer.

The development of the national liberation movement in Ukraine, where different parts in the early twentieth century were ruled by Russia and Austro-Hungary, led to the emergence of theories that formed the basis of equitable rights to defend Ukrainian independence of the state, territorial certainty and public-political self-organization. Analyzing the historical development of the Ukrainian lands, S. Rudnytsky argues that a positive solution of the Ukrainian question, i.e. the formation of the Ukrainian national state in ethnographic borders is the answer to the last major issue in Europe. The scientist predicts that without solving the problem of the state formation in Ukraine, its lands will become the areas of potential conflicts: "The formation of the national state in ethnic boundaries is the only way to prevent plots and conflicts in south-eastern Europe. Without the national Ukrainian state we shall live in the shortest time to see new military and revolutionary disasters"'. Pondering over the problem why Ukraine in the early twentieth century was in such distress, S. Rudnytsky states that the reason for this is the lack of national consciousness among the Ukrainian intellectuals. "The Ukrainian people have the right to require from their intellectuals not to ignore the affairs of their native land." 2

The fact that Western Ukraine was long ruled first by Poland and then by the Polish-Lithuanian Commonwealth and Austro-Hungary, Central and Eastern Ukraine, being under Russian authority, was affected in terms of culture, traditions, and religious identity of the population. The population of Western Ukraine is predominantly Ukrainian and adheres to Greek-Catholic church being quite nationalistic. People of the Central and Eastern part of Ukraine indentify themselves with the Orthodox Church (at least consider themselves an Orthodox cultural civilization), and a considerable part of them speak Russian as their native language. This indicates that in the territories of Ukraine there is a civilizational distinction between the Western Christian and the Eastern Slavic-Orthodox world. This cultural and civilizational specificity of Ukraine affects both the two-vector orientation of the national elite, philosophical systems of the masses and the state's two-vector orientation in the foreign policy.

\footnotetext{
${ }^{1}$ S. Rudnytsky, Why We Want Independent Ukraine? / Compilation and introduction by O. Shabliy, Lviv 1994, p. 145.

2 Tamże, p. 346.
} 
The specificity of the cultural and civilizational development of Ukraine actualizes the research of S. Rudnitsky's papers that still have importance for the Ukrainian state formation and Ukrainian people's self-identification in the European process of democratic renewal. In terms of great upheaval associated with the First World War, the collapse of empires, and the October Revolution in Russia, S. Rudnytsky develops the idea of strengthening the independence of Ukraine. The scholar emphasizes that the Ukrainian people are a large independent nation of forty million people, which is different from the Moscow, Belarusian, Polish and other neighbouring nations. They have led their lives for centuries, and then for many centuries they were oppressed by alien domination. Now they want to live their own way. S. Rudnytsky writes that Ukraine, developing on the border of the three worlds - Western, Islamic and Asian nomadic, has preserved its own uniqueness, which is seen on its territory where other races, cultures, and nations interact. Therefore, Ukraine appears as a country of frontiers ${ }^{3}$.

In his study S. Rudnytsky considers the territory of Ukraine as the Independent State within the world geopolitical reality, which means that firstly, Ukraine occupies a separate territory in the South of Eastern Europe and it is bigger than all European countries except Russia; it is rich in natural resources. Secondly, Ukraine is an independent state body, although for long ages its territory was divided between other countries: Poland, Austria-Hungary, and Russia. For S. Rudnitsky it was clear that Ukrainians will gain independence only when they become true masters in their homes. He opposes those who claim that the Ukrainian people have no capacity for political and public life. For them, it is recalled that the Ukrainian people created their own state three times. Despite two declines of its political independence, the nation has not only managed to preserve its independence, but it also remains the largest state in Europe. Therefore, the statements about the Ukrainian people lacking state formation capacity are groundless.

The concept of nationalism of S. Rudnytsky was a reaction to the political crisis caused by the defeat of the Ukrainian state-forces during the liberation struggle of 1917-1920. This concept was based on the specifics of the geopolitical situation of Ukraine and the idea of natural rights of nations to have their own state without violating the rights of others. In the early twentieth century the scholar proved that Ukraine had all the conditions to become not only a major power in Europe but also the world. In terms of geography,

${ }^{3}$ Tamże, pp. 98-208. 
culture, and history he reasoned a scientific truth: Ukraine is an ancient nation with the unique history, culture, language, and territory. The fact that this nation does not have its statehood is "a shameful stain on the body of the whole mankind."

The culture of Ukraine has integrated cultural values of many nations. Since ancient times, through the Silk Road, Tin way, "the way from the Vikings to the Greeks", the population of Ukraine forged ties with both the West and the East. The culture of the peoples who inhabited the territory of Ukraine in the first millennium BC was greatly influenced by the Greek culture. The existence of ancient Greek cities in modern Ukraine, and later the appearance of Byzantine, Roman, Genoese, Venetian and Turkish colonies and their trade relations with the Slavic tribes had an impact on the Ukrainian culture and spirituality of the people. Ukrainian ancestors had direct links with the peoples of the Caucasus, Mesopotamia, Persia, the Byzantine Empire, the Ottoman Empire, the Balkans and other countries. On the territory of the modern Ukraine establishments of eastern and western Goths, Avars, Huns, Khazars, Pechenegs, and Crimean Tatars existed. Impacts of these peoples affected the cultural features of Ukraine, which was at the crossroads of Eastern and Western civilization axes. The relations with the East and West are compounded by Kievan Rus $\left(9^{\text {th }}-13^{\text {th }}\right.$ century). With the adoption of Christianity Kievan Rus started expanding the cultural space of relations with other Christian countries attached to their cultural heritage. The adoption of Christianity to Eastern rite expanded the state's cultural space, made civilization structure of the Eastern Byzantine world and brought macroethnicity to the East Slavic community. However, Kievan Rus became able to join the culture of Christendom only with the adoption of Christianity. From Byzantium in Kievan Rus alphanumeric phonetic writing was extended. The Church contributed not only to the translation of the Holy Scripture into other languages but also to the creation of a writing system for people who did not have it. The Christian educators Cyril and Methodius are considered the ancestors of the Slavic literatures. The period of reign from Vladimir to Yaroslav was focused on Orthodox Christianity with the Church Slavonic language. It was the time when the foundations for the Eastern Orthodox civilization were laid.

\footnotetext{
${ }^{4}$ Tamże, p. 6.
} 
After the collapse of Kievan Rus and the loss of its own state the conditions for the development of the Ukrainian culture were unequal in different parts of Ukraine. Most of the Ukrainian territory became part of the Grand Duchy of Lithuania where there were numerous features of the administrative structure and law that had come from the Kievan state. The official language of the Grand Duchy of Lithuania, where Lithuanians, Belarusians, and Ukrainians were united by single faith and had common political and cultural interests, was the so-called "Russian language" under which they understood the common literary language of Belarusians and Ukrainians.

In those days when there existed the land's own statehood (GalitskVolyn principality), or at least some elements of a state or an autonomous political organization (Kiev appanage principalities in the political system of Hedyminovychiv, the territorial administrative structures of Zaporizhska Sich, Registered Cossacks) started recovering of the damaged and new ways were built. The administrative work was also put right into order. After the loss of independence the Ukrainian lands preserved the culture and traditions inherited from Kievan Rus. Following the ancient traditions the translated and original works were copied, new translations of monuments of those genres that were known before penetrated from South Slavs. Kiev-Pechersk Monastery remained as the most important centre of literacy. Whilst in daily writing the language close to the colloquial one was used, in liturgical and theological texts and literary works of "high style" the Church Slavonic language still dominated, based on a long tradition of the national culture.

The cultural development of Ukraine largely depended on the political situation. Relations between different regions of Ukraine were often destroyed: at the time of disintegration, during the period of Ruin. The Western Ukrainians for a long period of history made the part of the Kingdom of Poland, which East Galicia joined in the middle of the fourteenth century. And later it was a part of the Polish-Lithuanian Commonwealth and the Austro-Hungarian Empire. In that area Magdeburg law was in force and the courts independent of secular and ecclesiastical authority existed. Ukrainians living on these lands had the opportunity to study at universities in Europe. All this, of course, had an impact on the mentality and culture of the population of Western Ukraine. Representatives of the educated population of this region often took the union or were converted to Catholicism and identified themselves with the Western Christian civilization 
in its Polish Catholic form. Overall in Western Ukraine there was formed a kind of socio-cultural environment in transition when the Western Christian civilization was to face the Eastern Christian civilization.

After Lublin (1569) and Brest Unions (1596) in Ukraine the problem of "East-West" was becoming acute. Ukraine, having joined both the Western Christian and Orthodox cultural civilizations, found itself at the crossroads of the East and the West. The historical fate of the Ukrainian lands, while they were within certain countries, influenced the formation of cultural and social life. State boundaries served as factors of regional isolation and culture formation leading to limited communication between them. After the collapse of Kievan Rus most of the Left Bank was the part of Pereyaslav principality, the Right Bank belonged to Kiev. In 1654 the Middle Dnieper Left Bank became Hetmanate, which was under the protection of the Moscow Tsar and the Right Bank of Ukraine remained within the Polish-Lithuanian Commonwealth.

In 1654 after Pereyaslav Rada one of the most important factors of the Ukrainian lands development was the fact of their being the part of the Russian Empire. There was a rupture of relations with the Polish-Lithuanian Commonwealth and although the Europeanization of Russia, including the Ukrainian lands, started in the beginning of the era of Peter I, it was pretty shallow. Only educated people who belonged to the upper circles of the Ukrainian Cossacks were able to master the Western culture. The Cossack leaders, who had long been the elite of Ukraine in the $18^{\text {th }}$ century, were affected by russification and turned into the Russian nobility, though some of them preserved their national values and interests.

With the inclusion of the Right Bank in Russia in 1772 the degree of integration with the Russian culture among the population was relatively low, and the area remained a zone of dominance of Polish cultural influences, including Kyiv where the language of the intellectual life of 1830s was Polish. After the suppression of the Polish uprising of 1830-1831 Kyiv was gradually becoming a Russian enclave city of the Ukrainian rural population. Russia conducted a deliberate policy of russification of the Ukrainian people. In 1720 printing of books in the Ukrainian language (except liturgical publications) was banned by the decree of Peter I. The continuation of this policy was the publication of the tsar's decree, which banned teaching of the Ukrainian language in Kyiv-Mohyla Academy (1753), the prohibition of the Synod of the Russian Orthodox Church to print the Ukrainian primer (1769), the publication in July 1863 by P. Valuev, the Interior Minister of the 
secret circular on banning "Little Russian dialect" books of spiritual content, educational and generally intended for the initial reading books for people. Printing in the Ukrainian language was allowed only for artistic works. It was only in the early 1870s when censorship weakened and the Ukrainians were able to resume their publishing activities.

S. Rudnytsky made geopolitical "conclusion on the Ukrainian people's rights", based on the following ideas: "Surely only in the independent Ukraine the Ukrainian people can be transformed from the dark mass of impoverished into a conscious and modern one" and "Autonomy and independence only make the Ukrainians true masters in their own land." He believed that the ultimate goal of all Ukrainians should become a complete state independence of Ukraine, because neither autonomy nor the federal portion will give people the most complete environment for national and socio-political development. When asked "What kind of independent Ukraine do we need?" S. Rudnytsky gave the following answer, which sounds implicit on central thesis: "The Ukrainian people must really be the masters of their own land... We recognize the foreigners' rights living among us to freely develop, but Ukraine should be owned only by the Ukrainians" ${ }^{\text {. }}$

S. Rudnytsky substantiated the fundamental principles of the state policy framework as the basis of human organization. He condemned the principle of "autocracy", which was implemented in the so-called "mosaics countries" - Austria-Hungary, Russia, the "class" principle, which became a major in the formation of the Soviet Union. The national principle must be determining in nation-building, and all others contradict the conventional position on the right of nations to self-determination. "The Ukrainians' claim for an independent national state is not any luxurious whim of a chauvinistic nationalism, but a bitter necessity ... Without Ukrainian statehood forty millions of the Ukrainians divided in four neighbouring states would come under cultural death."

S. Rudnytsky expresses a big number of political and geographical theories which best describe the identity of the Ukrainian people and he gives a historical analysis of the development of the Ukrainian lands. "When Poles, Czechs, Yugoslavians got their national states, it is a matter of basic fairness ... The great word "self-determination" of all nations should be also applied

\footnotetext{
${ }^{5}$ Tamże, pp. 88-89.

${ }^{6}$ Tamże, p. 89.

${ }^{7}$ Tamże, p. 144.
} 
to Ukrainians ... Ukrainians are larger in population than those mentioned nations altogether, they have a larger territory than the others, their cultural level is not lower. Thus, they must have their own national state"

Addressing the Ukrainian state, he sees the ideas of nationalism as ideological, organizational, and practical foundations of every nation, not only of the Ukrainian one. "Nationalism is an orientation of thoughts, words or actions of a unit or group in the direction which is highly useful for the development of the nation to which this unit or group belongs."

Proving the identity of the Ukrainian nation, S. Rudnytsky devoted considerable attention to the language issue. "Language is a domineering sign of nation, as if it was a military uniform. And at the same time it is the most beautiful expression of the spirit of people and a single lever of spiritual progress. When we deprive people of their language, they will live only as a racial group among other people having taken over the language" ${ }^{10}$. The language issue in the process of nation formation remains important even today. After all, it is much more than a form of social communication. It displays all the socio-cultural changes, as it is a way of constructing images of reality in man's consciousness and designing the world in which the man lives. With the help of thinking a human builds a picture of the surrounding world, and this pattern is reflected in language. It is, on the one hand, focused on thinking: this is what fills language with content; on the other hand, it is addressed to the world: through the language thinking and content are imposed on external influences interpreting them in the way of objects. And its origins lie in the depths of the human civilization history.

Analyzing why Ukraine was in such distress in the early twentieth century, S. Rudnytsky simultaneously states that the reason for this is the lack of national consciousness among the Ukrainian intellectuals. "Those who consider their native land only as a theoretical concept will never be able to properly serve the native people. Sound nationalism, which is the so-called "cultural nationalism of modern people", opposes philistine (vulgar) nationalism, chauvinism, and "universalism". The scholar names four main types of universalism: 1) state-legal, which begins its history from the medieval feudal nation-states; 2) religious universalism, which is based, according to him, on ignoring any differences between people; 3) capitalist universalism, which

\footnotetext{
8 Tamże, p. 142.

9 Tamże, p. 276.

${ }^{10}$ Tamże, p. 54.
} 
strives for levelling differences among human groups on economic basis; 4) social-communist universalism, which removes the differences on class principle, completely levelling national characteristics of the community. These words of S. Rudnytsky sound as a political testament: "All Ukrainians have to find out that true modern nationalism is not a party matter. We should understand that we must think in a national way despite any party distinctions: from anarchists and communists to extreme rights"11. For the first time in the history of the Ukrainian science S. Rudnytsky made synthesis of history, philosophy, political, and physical geography to justify the independence of Ukraine as a particular geopolitical reality. The scientist showed that Ukraine is a separate territorial and natural unit of Eastern Europe. He was firmly convinced that without resolving the issues of all nations, and especially of Ukraine's one, the world would hardly be peaceful.

Currently Ukraine, which is inherent in ethno-cultural and religious diversity, is experiencing a split in society. This challenge requires from the society a great deal of tolerance as a primary condition of consensual solutions that unite society. Intolerance in relation to one or another socio-cultural, political community, and societal attitude, as well as the focus on corporate interests must be replaced by a focus on human values. The recognition of cultural diversity is only the first step towards interaction and there is not yet a guarantee of communication success. For a positive result it is important not to have only the recognition of differences. It is much more important to understand how important the cultural diversity is. This factor can equally serve as a partnership and cooperation factor, as well as a conflict provoking one. It is dangerous for society to propagate ideas which can contribute to the awakening of racial, national ethnic, and social identity awareness that distract from common human values. This leads to social tension, to revolutions, civil and civilization wars. Acceptance of differences and search for the foundations of peaceful coexistence is impossible outside the communicative paradigm. At its core there is a direction on the dialogue and interaction, on cooperation and partnership. It is important that the process of communication put the emphasis not on isolation due to cultural differences, but on the unity through diversity.

\footnotetext{
${ }^{11}$ Ibid. Tamże, p. 346.
} 


\title{
References
}

Rudnic'kij S., Čomu mi hočemo samostijnoï Ukraïni? / S. Rudnic'kij; Uporâdnik ta avtor peredmovi O. İ. Šablij. - L'viv: Svit,, 1994. - 416 p. (Rudnytsky S., Why We Want Independent Ukraine? / S. Rudnytsky, Compilation and introduction by O. Shabliy. - Lviv, 1994. - 416 p.).

\begin{abstract}
The article investigates the philosophical views of the Ukrainian scholar S. Rudnytsky, who justifies the Ukrainians' right to establish their own national state on the basis of his analysis of historical development, geopolitical situation of Ukraine, and the idea of natural right of the nation to have its own state.
\end{abstract}

Key words: Ukraine, culture, civilization, nation, state, S. Rudnytsky 